\title{
Application issues of spatial interaction marketing in the regional agribusiness sustainable development
}

\author{
Innessa Efremenko $^{1 *}$, Victoria Bondarenko ${ }^{2}$, Tatiana Romanishina ${ }^{3}$, Dmitry Rudoy $^{1}$, and \\ Anastasiya Olshevskaya ${ }^{1}$ \\ ${ }^{1}$ Don State Technical University, Gagarin Square, 1, Rostov-on-Don, 344003, Russia \\ ${ }^{2}$ Rostov State Economic University, per. Ostrovsky, 62, Rostov-on-Don, 344000, Russia \\ ${ }^{3}$ Russian State University of Tourism and Service, Pushkinsky District, dp Cherkizovo, st. Home, 99, \\ 141221, Moscow Region, Russia
}

\begin{abstract}
The purpose of the research is the defining the role of spatial interaction marketing in agribusiness sustainable development in the framework of the general focus on the positively evolved regional economy. We relied on a meaningful analysis of literature sources, expert opinions representing the value guidelines of the concept of sustainable development, changes in marketing theory, social attitudes that characterize the success of business relationships and the essence of the concept of marketing of spatial interaction. We have examined the points of view on ongoing initiatives in terms of the agribusiness projects development in a number of Russian regions. The following methods were used: analysis of the content of literary sources, expert opinions, analogies, meaningful and comparative analysis, synthesis of the data obtained in obtaining conclusions. An important result is the substantiation of the approach to the fact that changes that take into account modern targets for the positive evolution of the territory and its agribusiness sustainable sector are in the pool of solutions for the spatial interaction marketing, practical implementation of which will take into account, along with economic, social and environmental effects, that will give impetus to the necessary transformations for the sake of common interests.
\end{abstract}

\section{Introduction}

Marketing of spatial interaction in relation to various areas of positive evolution of territories is of certain interest in the current business practice, since it combines the target guidelines of the social and ethical orientation of business with the establishment of longterm mutually beneficial partnership relations between business partners and consumers. The issues of the benefits of the priority decisions being made are interpreted in its ideological content, taking into account social and, accordingly, environmental prerogatives [1]. In this regard, it can be considered as a variant of marketing sustainable development in relation to the problems of the functioning of the regional economy, which is localized in a

\footnotetext{
* Corresponding author: efremenko@yandex.ru
} 
certain economic space, consisting of internal and external players interested in a positive transformation of the socio-economic system of the region [2].

It is this marketing concept that is in demand in the current economic reality, since in the current situation, when choosing a vector for the evolution of society and the economy, the adoption of sustainable value orientations becomes characteristic of all industries and spheres of management [3]. Environmental and social orientation, along with a focus on innovation, is a priority for transforming the regional economy [4, 5]. Accordingly, the agricultural sector, in this sense, is no exception, and also becomes the object of application of solutions within the framework of the concept of sustainable development.

Within the framework of sustainable development targets, economic activity is carried out to achieve three equally significant effects, such as economic, environmental and social [6-9]. Accordingly, territories conducting agricultural activities, specializing in the development of agribusiness, become involved in a process associated not only with obtaining the desired profit, but also solving a number of social problems, for example, the employment of human resources concentrated in the region, adapted to the working conditions in the field of agricultural processing. products, as well as environmental issues aimed at minimizing the harmful burden on the environment and reducing the use of nonrenewable resources in favor of renewable ones.

Since we are talking about market priorities and the need for successful business functioning in the field of regional agribusiness, marketing practice should be aimed at resolving a number of issues associated with a combination of economic interests of business circles and the local community regarding the construction of socio-ecological systems [10].

According to the prevailing point of view, the implementation of the concept of sustainable development in the strategy of the positive evolution of the territory (for example, the agricultural sector) is possible when environmental well-being is included in the built brand of the territory, promoted in the interests of both external consumers (guests) and internal audiences who associate their future with this territory $[11,12]$. Coordination of the interests of investors (external and internal), local authorities, entrepreneurs involved in the agricultural sector of the region and the local community in terms of environmental priorities, allows in a prolonged perspective to focus also on achieving the planned economic effects [13-17].

The above implies clarification of the essence of the concept of marketing of spatial interaction within the framework of understanding the development of marketing theory in connection with changes in business conditions, validation of the accepted criteria for the success of doing business in the agricultural sector of the region, focused on public interests in combination with the interests of business and the local community in the context of value attitudes on sustainable development.

This formulation of the question seems to us reasonable, since the agricultural sector is significant in the economy of a number of Russian regions, in part it is typical for the South of Russia. For this reason, finding, within the framework of the demanded marketing concept, the direction of the territorial development of agribusiness, subordinate to the interests of society and business, not only at the moment, but taking into account the emphasis on the possibility of prolonged consumption of future generations, is relevant to us.

\section{Materials and methods}

In focusing on the study of the role of marketing of spatial interaction in the sustainable development of the regional agribusiness, we relied on a meaningful analysis of literature sources, expert opinions representing the value guidelines of the concept of sustainable 
development, changes in marketing theory, social attitudes that characterize the success of business relationships and the essence of the concept of marketing of spatial interaction. We have examined the points of view on ongoing initiatives in terms of the development of agribusiness projects in a number of regions of Russia. The article uses research methods such as: analysis of the content of literary sources, expert opinions, analogies, meaningful and comparative analysis, synthesis of the data obtained in obtaining conclusions.

\section{Discussion}

In the ongoing efforts for the sustainable development of agricultural production, the regional agribusiness, a number of experts, along with positive consequences, highlight possible negative ones that may be associated with a decrease in investor interest in the region due to an increase in spending on the environmental component. In this case, the result may be an increase in social tension due to the outflow of business and the reduction of jobs in agriculture, as a result, the deterioration of the environmental situation due to a decrease in the level of funding for projects [18].

In our opinion, the prevention of such negative consequences is possible and lies in the plane of marketing decisions, consisting in the formation of a favorable and attractive image of the territory for investors $[19,20]$, their awareness of the support of the regional authorities in the range of projects undertaken in the field of the regional agribusiness, related, for example, with "green" innovations, which will contribute to the growth of confidence in the initiatives carried out in the territory and the desire to participate in investments in these promising areas[33,34].

The importance of the "green" growth of the regional economy associated with the regional agribusiness is noted in studies, for example, by M. Dudin, S. Kalendzhan, and others, emphasizing the importance of innovations being introduced [21].

Mirzekhanova Z.G. focuses on the ecological component in the agricultural sphere of the regions while finding a promising model of economic development [22], suggesting to rely on the existing world experience in this matter [23].

We emphasize that under the marketing of spatial interaction, we, relying on the opinion of other scientists, as they do, mean a complex persistent process, finding resources, opportunities, forming an economic space and obtaining values from long-term relationships between participants in the process [24].

Consumers (in this case, stakeholders of the territory) are the main (as it should be in the theory and practice of marketing) persons whose multidirectional needs are specified and anticipated with a simultaneous focus on the rational use of all types of resources and with an emphasis on social development [24,32].

The marketing component of ensuring territorial development (as applied to the agribusiness in the case of our study), in which the quality and effectiveness of interaction of subjects in a certain space are analyzed, is also reflected in other scientific works that develop the role of practical interpretation of the concept of marketing of spatial interaction $[25,26]$.

In the noted context, the purpose of the article is to determine the role of marketing of spatial interaction in the sustainable development of agribusiness in the framework of the general focus on a positively evolved regional economy.

\section{Results}

In a practical sense, the concept of marketing spatial interaction in relation to agribusiness of a region implies the possibility of taking into account the interests of internal and 
external target audiences of a certain territory, such as agro-industrial enterprises, regulatory bodies, internal and external investors, residents of the region working in agribusiness, residents of the region who consume products that depend on the well-being of this area, guests of the region (including the segment of agrotourists) in the undertaken positive transformations focused on the current and prolonged effects.

Let us repeat, the key setting of the concept of sustainable development, consisting of three basic effects, should be included in the spectrum of the main value guidelines for the sustainable development of the regional agribusiness (Fig. 1).



Fig. 1. The spectrum of the main values of sustainable development of the regional agribusiness [27].

Within the framework of territorial marketing, in general, as we have already mentioned, the target audiences, interested parties who express an interest in the territorial territory, are the authorities in the region; business localized in the region, enterprises and organizations; the local community (the population connecting their career and personal destiny with the region), as well as external investors, third-party businesses, partners of the territory and individual consumers of the territorial product, for example, guests of the region.

As part of the involvement of marketing theory - marketing of spatial interaction in aligning the model of sustainable development of the regional agribusiness, such long-term relationships will be built between internal and external players focused on environmental and social effects, in addition to purely economic ones (Fig. 2). 


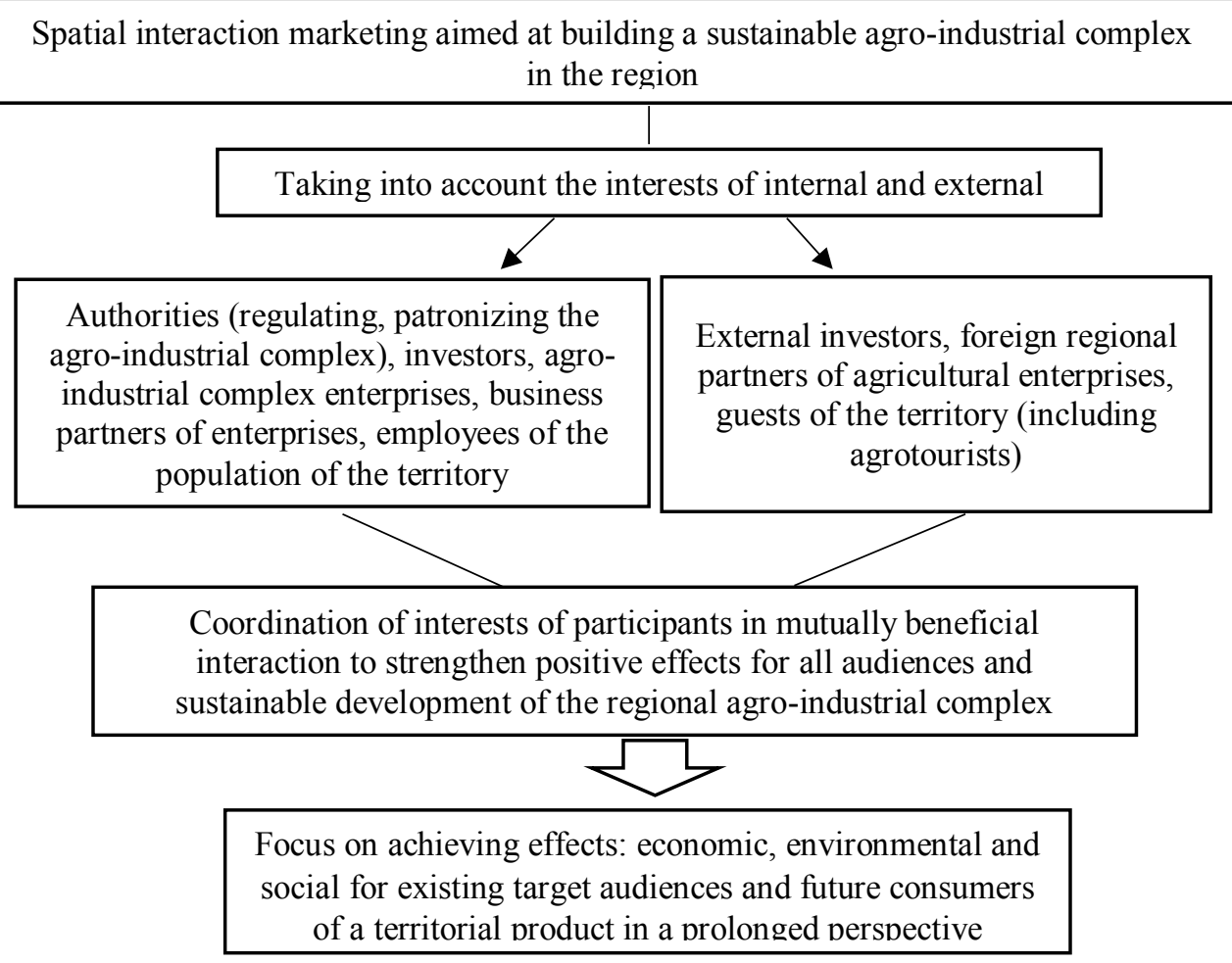

Fig. 2. Marketing of spatial interaction within the focus on sustainable development of the regional agribusiness. Compiled by the authors.

It seems important that the business is ready to sacrifice part of the profit in the current situation, focusing on social needs, environmental goals and a strategic perspective, in which the needs of future target audiences will manifest themselves.

In such a situation, marketing is not aimed at the desire to intensify consumption at any cost, but creates the preconditions for conscious consumption, which gives a chance to live and consume new generations in the future in a preserved landscape. This presupposes an initial assessment of environmental and social risks in the implementation of investment projects in agribusiness of the region, which are focused not on maximizing profits in a discrete time interval, but on creating a stable, workable business model, justified in a strategic perspective. Such a model, based on the principles of a market economy, involving marketing practices in its business "orbit", but providing for conscious selfrestraint, is used in various industries and spheres of activity.

As part of the development of sustainable development practices, the concept of marketing has evolved, changing its purpose from intensifying sales "at any cost" to a practical concept of long-term relationships of interacting parties in order to bring positive economic, social and environmental effects to all participants in interaction, including the local community.

In this vein, the interaction paradigm (in relation to the construction of a sustainable regional agribusiness) can be considered as an updated (compromise) approach to creating 
value in agribusiness of the region in the context of changed guidelines for socio-economic development (Fig. 3).
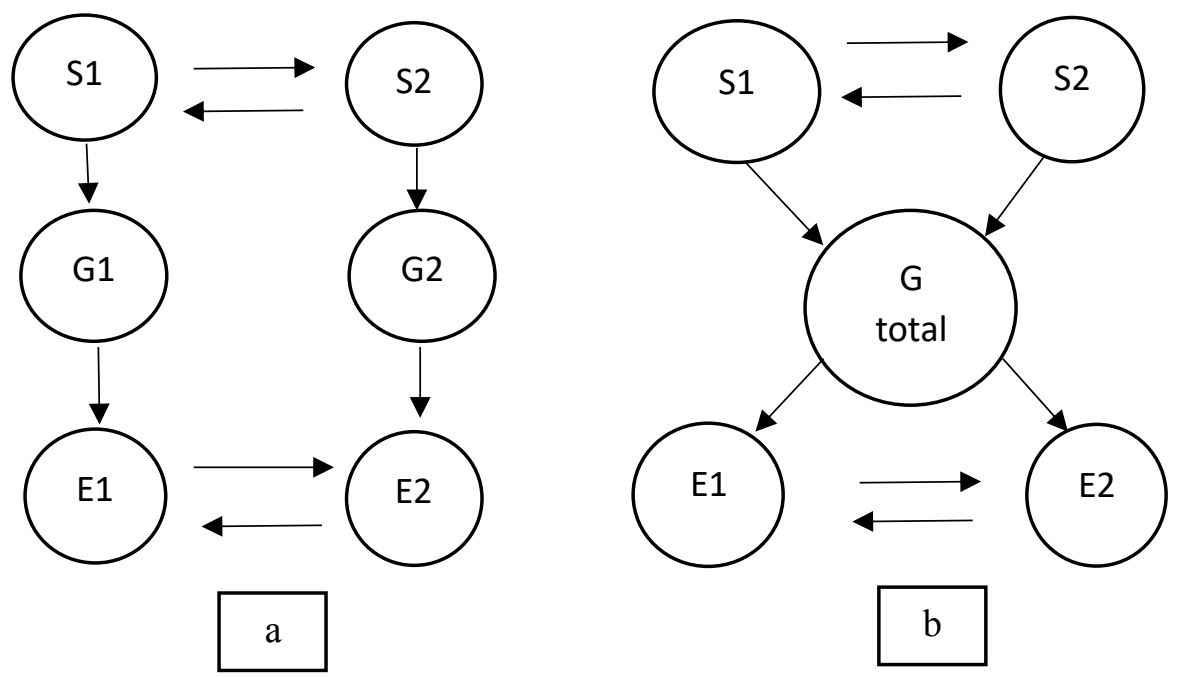

A - ratio (discrete), personified participants of value creation in the field of region agribusiness; B - interaction (long-term), implying common value attitudes and obligations of participants in the creation of value in the field of the region agribusiness, where S1, S2 - subjects of interaction; G1, G2 - the goals; E1, E2 - effects obtained.

Fig. 3. Visualization of the differentiation of discrete relations and long-term interaction of the subjects of value creation in the field of agribusiness of the region in the context of changing value attitudes [24].

When interpreting the presented visualization, let us explain that within the framework of discrete relations, the goals of the interacting subjects are multidirectional, focusing on achieving private interests without taking into account the interests of the industry as a whole and society. In the case of the practical implementation of the marketing of spatial interaction in the form of long-term contacts of the parties in agribusiness, the partners cooperate with an emphasis on compromise goals that combine economic, social and environmental effects that are justified for the current situation and the future of the territory.

For the regions of Russia, such decisions will appear, in our opinion, justified [28]. They can find practical implementation, both within the framework of strategic steps for the development of territories with a traditional agrarian orientation, and those that are currently underdeveloped [29]. For example, in the Far Eastern Federal District, where 18 territories of advanced socio-economic development (TASED) are developed out of 200 ongoing projects, about $20 \%$ are in agriculture [22,31]. For example, in the Khabarovsk Territory, within the framework of the investment strategy, the agro-industrial sector of the region is considered among the priority sectors. A similar situation is typical for the Amur Region. Russian and foreign (mainly Japanese investors) are involved in the implementation of these projects.

At the same time, experts have certain well-founded fears that in the ongoing project initiatives in the agricultural sector in the Far East, the emphasis is on economic indicators, 
without due regard to environmental and social consequences, marketing improvements and solutions within the framework of desirable "green" innovations [22, thirty].

In the southern regions of Russia, there are also certain difficulties associated with insufficient consideration of environmental and, accordingly, social effects in the implementation of business projects, including in the agricultural sector. The expert community considers such difficulties, for example, air pollution, insufficient amount of clean drinking water and irrational use of water resources for economic purposes, unsatisfactory condition of agricultural land, degradation of posts and vegetation, etc. [12]. So, in the strategic planning of the ecology of the regions of the South of Russia, which is extremely important for agribusiness, such components are determined as: identification of problems, setting goals and objectives, however, desirable scenarios, taking into account the interests of the parties involved, and mechanisms for achieving the set targets, are far from presented. in all territories, which also exaggerates the economic component to the detriment of social and environmental effects [35].

In a prolonged perspective, such a situation will complicate the possibilities of territorial development in terms of attracting investors, business partners, concentration of infrastructure, population and necessary resources for a full-fledged positive evolution of the regional agribusiness. This presupposes the need for a real revision of existing guidelines and the activation of the practical implementation of the concept of marketing of spatial interaction in building a sustainable sector of the regional agribusiness with a fullfledged prioritization of environmental and social components, along with economic ones.

\section{Output}

Within the framework of the current paradigm of the functioning of territories, in relation to the adoption of sustainable development goals, justified taking into account the evolution of marketing theory and practice, is the application of the concept of marketing of spatial interaction, focused on long-term transactions between business partners and consumers, which allows to regulate the interests of interacting parties with a common desire to obtain economic, social and environmental benefits. The adoption of such a model of relationships makes it possible to count on the creation of a stable sector of the regional agribusiness, which satisfies the interests of current target audiences and is aimed at future consumers in the distant future.

Currently, in the current Russian practice, in relation to regions with a traditional agaric orientation and territories newly developed from this perspective, there is an insufficient study of social and, in particular, environmental issues, there is a prevalence of the economic component in ongoing projects. This situation is a losing one in the medium and long term and needs to be corrected. In our opinion, positive changes that take into account modern targets for the desired evolution of the territory and its sustainable sector of agribusiness lie in the pool of spatial interaction marketing solutions, the practical implementation of which will take into account, along with economic, social and environmental effects, which will give an impetus to the necessary transformations in for the sake of common interests.

\section{References}

1. V. A. Bondarenko, A. V. Guzenko, N. V. Guzenko, I. N. Efremenko, "Green" Economy: Theory, Foreign Experience, Modern Problems and Prospects of Russia, in European Proceedings of Social and Behavioural Sciences EpSBS, Krasnoyarsk Science and Technology City Hall, Krasnoyarsk (2020) 
2. M. Bruhn, M. Kirchgeorg, H. Meffert, Marketing Weiterdenken (Springer, Gabler Verlag, 2018)

3. Sustainable Development Goals [Electronic resource] (2021), Access mode: https://www.un.org/sustainabledevelopment/ru/sustainable-development-goals/. Accessed 20.02.2021

4. B. Meskhi, V. Bondarenko, I. Efremenko, V. Larionov, D. Rudoy, A. Olshevskaya, IOP Conf. Ser.: Mater. Sci. Eng., 1001, 012100 (2020)

5. B. Meskhi, V. Bondarenko, I. Efremenko, T. Romanishina, D. Rudoy, A. Olshevskaya, E3S Web Conf., 217, 06012 (2020)

6. I. A. Rodionova, S. A. Lipina, Fundamental Research, 2 (24), 5462-5466 (2015)

7. N. V. Pakhomova, K. K. Richter, G. B. Malyshkov, Problems of Modern Economics, 3, 7-16 (2012)

8. N. M. Abdikeev, Y. S. Bogachev, M. V. Melnichuk, European Research Studies Journal, 21 (2), 411-425 (2018)

9. A. Altukhov, A. Semin, European Research Studies Journal, 21 (2), 753-771 (2018)

10. E. Ostrom, Policy Studies Journal, 39 (1), 7-27 (2011), doi: 10.1111/ j.15410072.2010.00394.x

11. K. Dinny, Territory branding. The world's best practices (Mann, Ivanov and Ferber, Moscow, 2013)

12. D.P. Frolov, A.S. Strekalova, Regional Economy: Theory and Practice, 19 (394), 2-11 (2015)

13. F. Barca, Ph. McCann, P. Rodriguez-Pose, Journal of Regional Science, 52 (1), 134 152 (2012)

14. T. Farole, A. Rodriguez-Pose, M. Storper, Progress in Human Geography, 35(1), 5880 (2011)

15. O. Parent, A. Zouache, Journal of Institutional and Theoretical Economics, 168 (3), 488-518 (2012)

16. A. Rodriguez-Pose, Regional Studies, 47 (7), 1034-1047 (2013)

17. B. Saha, Journal of Interdisciplinary Economics, 25 (1-2), 69-89 (2013)

18. A. P. Sokolov, E. V. Ponomareva, Vestnik VUiT, 4 (32) (2014), URL: https://cyberleninka.ru/article/n/ekologicheskaya-sostavlyayuschaya-pri-razrabotkestrategii-ustoychivogo-razvitiya-regionalnogo-apk. Accessed 13.04.2021

19. V. A. Bondarenko, S. N. Dianova, T. A. Joom, M. A. Dubinina, European Research Studies Journal, 21 (1), 51-62 (2018)

20. V. A. Bondarenko, E. V. Pisareva, O. M. Kalieva, European Research Studies Journal, 21 (4), $72-78$ (2018)

21. M. N. Dudin, S. O. Kalendzhian, N. V. Lyasnikov, Economic Policy, 12 (2), 86-99 (2017)

22. Z. G. Mirzekhanova, Regional Economy: Theory and Practice, 16 (6), 1082-1096 (2018)

23. A.A. Ignatieva, Russia in the World Around: 2011. Sustainable Development: Ecology, Politics, Economics (Analytical Yearbook) (MNEPU, Moscow, 2011)

24. G. L. Bagiev, A. V. Pinchuk, E. G. Serova, A. O. Shulga, PSE, 4 (2021), URL: https://cyberleninka.ru/article/n/k-voprosu-formirovaniya-kontseptsii-marketingaprostranstvennogo-vzaimodeystviya. Accessed 09.03.2021 
25. O. V. Berezhnaya, E. V. Berezhnaya, K. S. Chikaeva, M. A. Polivina, V. I. Berezhnoi, European Research Studies Journal, 21 (2), 551-563 (2018)

26. A.V. Pinchuk, Izvestia SPbGEU, 2 (86), 112-115 (2014)

27. A.V. Pinchuk, PSE, 9, 230-234 (2014)

28. E. A. Lyaskovskaya, K. A. Grigorieva, Bulletin of SUSU. Series "Economics and Management", 12 (1), 15-22 (2018)

29. Z. G. Mirzekhanova, Regional Economy: Theory and Practice, 11, 54-65 (2016)

30. G. V. Sdasyuk, Nature Management and Modern Development of Modern Russia (Media-Press, Moscow, 2014)

31. E. Zubrilina, I. Markvo, V. Novikov, A. Beskopylny, L. Vysochkina, D. Rudoy, A. Butovchenko, IOP Conf. Series: Earth Envir. Sci., 403, 012063 (2019) doi:10.1088/1755-1315/403/1/012063

32. A. Altybayev, Ye. Naydenko, B. Meskhi, A. Mozgovoy, D. Rudoy, and A. Olshevskaya, E3S Web Conf., 175, $03019 \quad$ (2020) https://doi.org/10.1051/e3sconf/202017503019

33. B. Meskhi, V. Bondarenko, I. Efremenko, V. Larionov, D. Rudoy, and A. Olshevskaya IOP Conf. Ser.: Mater. Sci. Eng., 1001, 012100 (2020), doi:10.1088/1757$899 X / 1001 / 1 / 012100$

34. B. Meskhi, V. Bondarenko, I. Efremenko, T. Romanishina, D. Rudoy, A. Olshevskaya, E3S Web Conf., 217, 06012 (2020), https://doi.org/10.1051/e3sconf/202021706012

35. O. Kholodov, M. Kholodova, Z. Kolycheva, et al., IOP Conf. Ser.: Mater. Sci. Eng., 918, 012144 (2020), doi:10.1088/1757-899X/918/1/012144 